DOI: $10.31393 /$ reports-vnmedical-2018-22(1)-03

UDC: $611.711 .7: 572.51$

\title{
THE HUMAN SACRUM SHAPE: METAMORPHOSES AND RELATION OF ITS PARTS
}

Cherkasov V.G., Malikov O.V.

Bogomolets National Medical University (T. Shevchenko boulevard, 13, Kyiv, Ukraine, 01601)

Відповідальний за листування: e-mail: alexandrvm@ukr.net

Received 12 December, 2017; Accepted 26 January, 2018

Annotation. The human sacrum shape and its metamorphoses should be considered due to their effect, primarily mechanical, predisposing for the vertebral column function evolution. The aim of the study is to define the human sacrum shapes and explain for such variability. The object of the study is represented with 68sacrums obtained from the review collection of anatomical study preparations of the Bogomolets National Medical University Department of Anatomy. Each of the known human sacrum shapes represents the stage of the process of "sinking" of the sacral vertebrae bodies into the sacrum, with simultaneous fixation of external apices of their lateral parts in the sacroiliac joint. Generally, metamorphoses of the sacrum shape make up an accommodation for the new mechanical conditions as well as causal external factors. The sacrum continuously sustains multiple factors' effects in each moment of the human life, which affects its shape and metamorphoses. The analysis of the human sacrum shape and functions reveals important instances: first, certain parts of the sacrum don't preserve permanent relations; secondly, alterations in these relations keep to a certain sequence. This issue permits us to consider various sacrum shapes as sequential stages of the same process, occurring in the human body.

Keywords: sacrum, vertebral column, shape, functions.

\section{Introduction}

The sacrum is particularly important if regarded as the issue of comparative anatomy. The human differs from the animals not only by the intensive development of central nervous system, but fact that during evolution motion function was assumed by the lower extremities, due to straightening or unbending of the vertebral column, changing its position from almost horizontal to the vertical one. The weight of the upper body, head and upper extremities comes across the sacrum, burdening the lower extremities, the sacrum correspondingly being modified due to new mechanical conditions.

The aim of the study is to define the human sacrum shapes and explain for such variability.

\section{Materials and methods}

The object of the study is represented with 68 sacrums obtained from the review collection of anatomical study preparations of the Bogomolets National Medical University Department of Anatomy [3].

\section{Results. Discussion}

There is no alive being which wouldn't change with time. The shapes are continuously changing. This may be illustrated by the sacrum example. Any contraction and curvature of the lower extremities, various traumas of the body bones junction, rickets, vertebral column deformities, retention of the fetus at labour, inconsiderable alterations of the right and left body sides' equilibrium - all this quickly reflects in the sacrum condition, changing its shape. All conditions which may affect the sacrum shape changes may be casual, but the alteration would not be casual, representing an accommodation to the new mechanical conditions. Sacrum sustains permanent effects of various factors in each moment, which affects basic shape of the sacrum and its metamorphoses [1, 4].

The amount of the sacral vertebrae isn't the predetermining factor, the same should be regarded related to other peculiarities of the sacrum.

The altered human body position isn't just a consequence of a "turned" vertebral column related to its axis, joining both sacroiliac joints, resembling animals, when they may get on legs and stand straightforward [2]. When the animal stands on its legs, it forces its joints and makes the vertebral column position almost vertical one: the body turns related to the axis within the pelvic joints. All parts of the vertebral column preserve the same shape and the same relation, as with the habitual position of the animal. The animal must bend the knees, particularly the pelvic joints, which will provide for reducing pressure on the muscles of the pelvis and vertebral column, preventing the pelvic joints from unbending. As a result, no vertebral column bending is observed, except for the usual one [5, 8].

The conditions, predisposing for the human body vertical position, are absolutely different. The human body weight body load shifts onto the lower extremities, which is possible due to forced hip and lower leg muscles [6]. This could be rather impossible, due to quick muscle fatigability and unsteadiness of the position. So, the pelvic joints must be unbent, to shape the straight bone column, holding on the body from downward. The main load would be transferred to the passive skeleton (bones and ligaments), with the muscles acting as the space body position regulating elements. This necessitated bending the vertebral column back, which was accompanied by metamorphoses of its parts in separate regions, or across the whole vertebral column.

So, the vertebral column changed its shape in the region 
which became most rigid, i.e. in the lumbar-sacral region. Consequently, there has been shaped its bending upward (lordosis) with sharp bend in the point from the free department to the fixed one. This is how sacral promontory was shaped $[12,15]$.

A detailed study of the skeleton shows that only the closest to the sacrum vertebrae sustained dislocation. The cervical and lumbar regions, as well as the region of the sacrum above the 1st sacral vertebrae, preserved its relative position almost the same as it was before metamorphoses of the vertebral column position. Though, the shapes of some bends underwent secondary metamorphoses, which occurred after the vertebral column attained vertical position.

So, vertical position at motion is peculiar as a standard one only for the human, which is accompanied by unbending of the sacroiliac joints and formation of the protruding curvature in the lumbar-sacral region of the vertebral column.

Radlauer, who studied various aspects of the human sacrum, suggested grouping all its shapes in three groups, based on the alar topography related to the sacrum base. He dwelt on the fact that the middle of the sacrum base, shaped by the 1st sacral vertebrae body and upper joint processes, the auricular surface being attached to it, resides on different levels. In some cases proximal edge of the auricular surface resides below the sacrum base. Radlauer termed such sacrum as the "hypobasal" one. In other cases, proximal edge of the auricular surface and sacrum base reside at the same level. These are "homobasal" sacrums. Sometimes the proximal edge of the auricular surface resides above the sacrum base which is a "hyperbasal sacrum" [16].

As the body of the 1st lumbar vertebra produces visible protrusion over the base, in hypobasal sacrum, with rounded edges, similar to the other vertebrae bodies, it represents the "transitional" vertebra, which, despitethe lateral alar shaping, preserved certain autonomy. Its sacrum assimilation isn't finally expressed (Fig. 1).

The next stage of such assimilation is "sinking" of the vertebral body till the alar level, which is observed in homobasal sacrum (Fig. 3). Such sinking may be explained
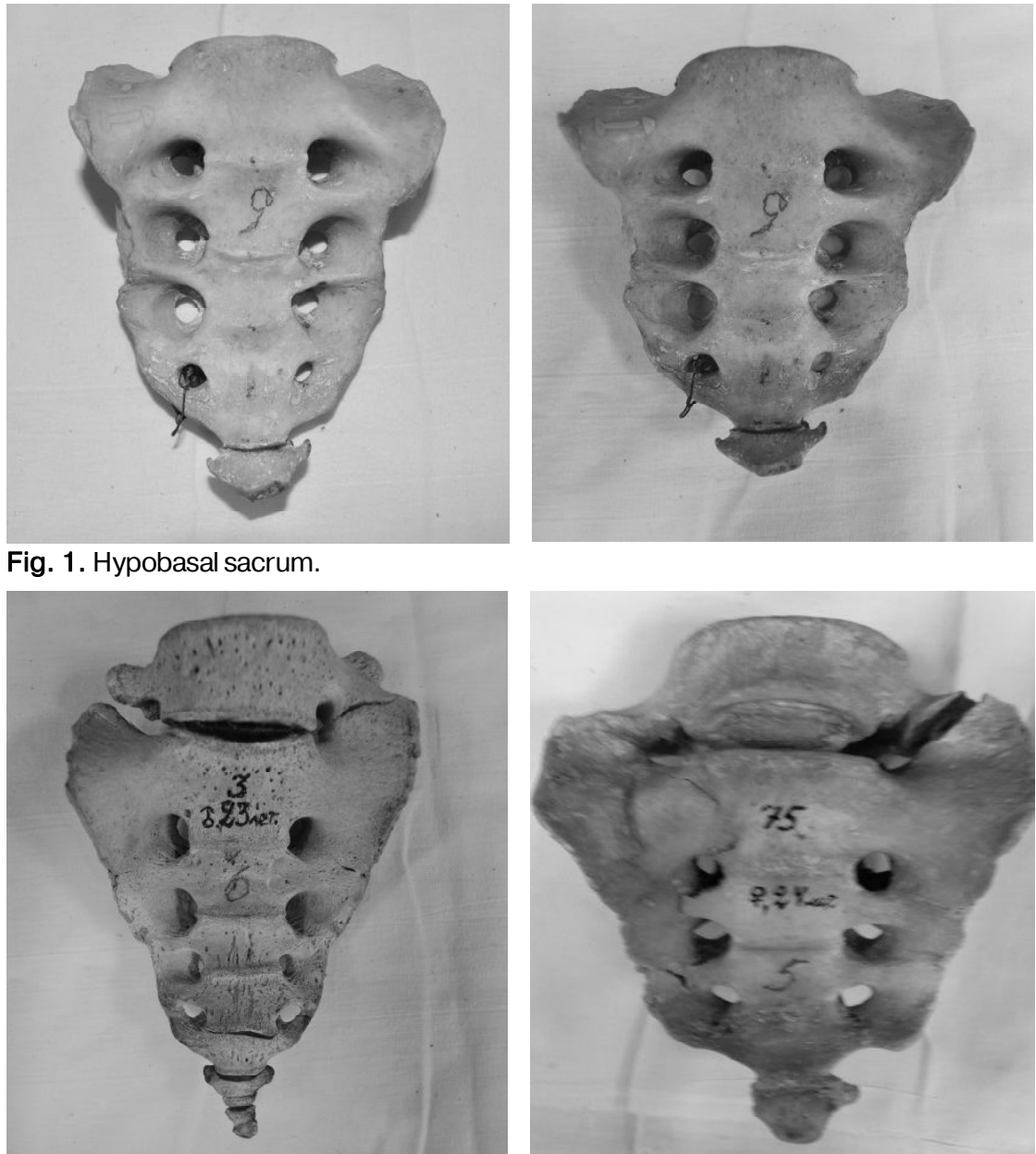

Fig. 2. Hyperbasal sacrum.
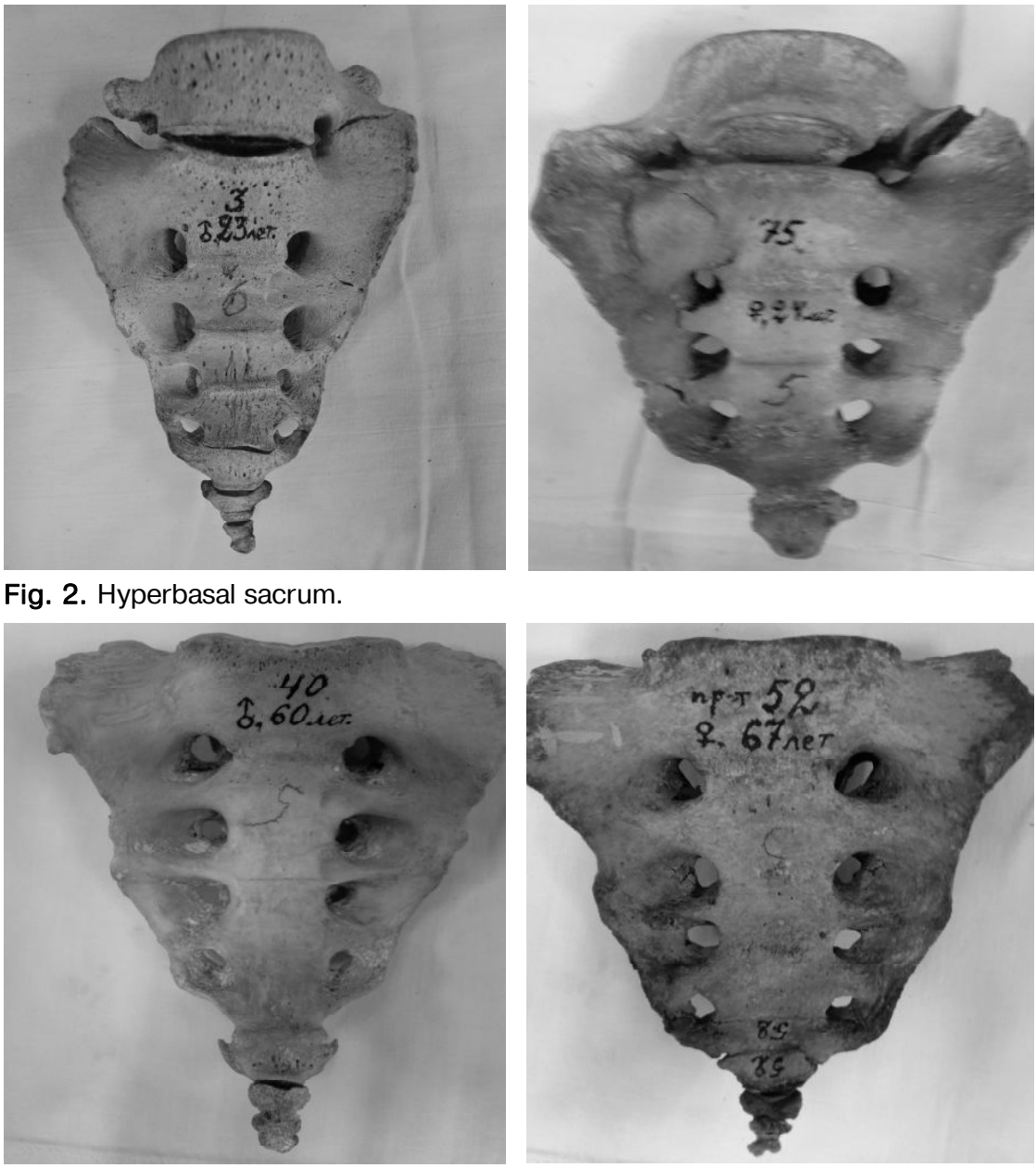

Fig. 3. Homobasal sacrum for the weight of the vertebral column, which relies upon the sacrum, presumably the vertebral region. Finally, hyperbasal sacrum represents the last stage of sinking of the 1 st vertebra body. From that moment the sacrum is shaped by the next vertebra, which is a sign of secondary hypobasal sacrum. Here, the hypobasal development somehow represent with pelvis being closer to the cranium (Fig. 2). 


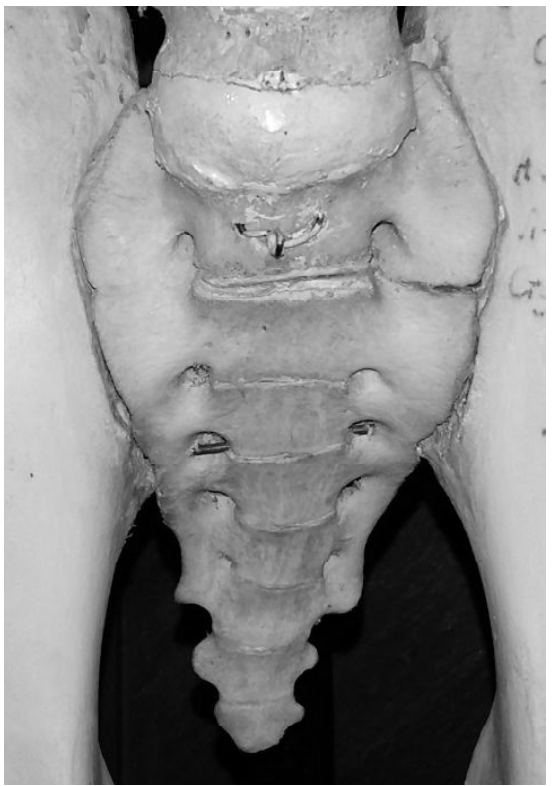

Fig. 4. Sacrum of hominids.
It is definite that sinking vertebra bodies into thesacrum cannot occur during the lifecycle of only one human, but the phylogenetic process, being a slow process, confirmed by heredity.

The innominate line near the abdominal surface margin of the 1st sacral vertebra lateral process, denotes the position of this process, which, in its turn, predisposes

for the sacrum shape.

The 1st vertebra body height is considerably higher anteriorly than posteriorly, as the upper part of the vertebra produces a kind of pedestal, supporting the free part of the vertebral column and its promontory.

If the innominate line is horizontal, its utmost apex will correspond to the middle of the 1st vertebra. Is the utmost apex of innominate line is located above the 1st vertebra body, the lateral process attains upward direction (hyperbasal). The direction of the process is the downward one (hypobasal), if the mentioned point is located lower. The expressed hypobasal process may be defined if the utmost apex of innominate line is located below the level of the first transversecrest of the sacrum (lin. transversa), slightlyexpressed hypobasal process - when the line is above it [10, 14].

The relation of various parts, which shape the sacral vertebrae, differs. Hypo- and homobasal sacrum are different in the 1st vertebra body height and the alar processes position. The lateral mass joins the vertebral body in the same point.

The analysis of the shapes and functions of a human sacrum provides for important circumstances to be found out: firstly, certain parts of the sacrum don't preserve permanent relation; secondly, metamorphoses of the relation occur in a certain sequence.

This issue provides for regarding various sacrum shapes as sequential stages of the same process, occurring in the human body. The basic part of the process is "sinking" of

\section{References}

1. Holovatskyi, A. S. \& Cherkasov, V. H. (2010). Anatomiia liudyny. [Anatomy of a person]. Vinnytsia: Nova Knyha - Vinnytsya: New Book, 368

2. Korzh, N. A., Staude, V. A. \& Kondratev, M. Yu. (2015). Napryazhyonno-deformirovannoe sostoyanie kinematicheskoj cepi "poyasnichnyj otdel pozvonochnika - the sacrum vertebrae into the whole sacrum, while the utmost apices of lateral vertebrae, being attached in the sacroiliac joints, are held on and shifted towards the cranium [9].

The most possible cause of plunging of the sacral vertebrae is the free vertebral column pressure, the vertebral column assuming horizontal position, completely relies upon the sacrum. It's controversial, whether this circumstance causes merging of further lumbar vertebrae with the sacral one and approaching of the cranium and pelvis.

Generally, vertical position of the vertebral column, with unbent sacral-iliac joints, is peculiar only for the human, being a human peculiar trait. All the consequences of this typical peculiarity may be considered as typical ones. The shaped curve of the lumbar region and vertical vertebral column position (further direct) arealso observed in hominids. Though, these signs haven't received such development as in a human. The hominids take up a transitional position, being both two-legged, and four-legged [7, 11]. Due to this their sacrum undergoes the same effects as the human sacrum, exerted in the same direction, but to a lesser degree. So, metamorphoses of the sacrum in the hominids wouldn't be so expressed as in the humans (Fig. 4).

\section{Conclusions and perspectives of further development}

The difference in the sacrum shapes is predisposed for the fact that the lateral vertebral parts may variously angle with its body. The lateral parts of the sacral vertebrae are shaped by two separate departments, different in their functions and origin. Their posterior part corresponds to the transverse processes of other vertebrae, abdominal part - to the ribs.

The development of abdominal departments starts with the independent points, to be joined with appropriate vertebra later, by only one bone.

The back departments of the lateral sacral parts, and, first of all, of two upper sacral vertebrae, are easily detectable by shape, resembling the transverse processes of lumbar vertebrae.

The study of relation of the lateral parts and bodies of the sacral vertebrae shows that in various sacral shapes the difference in relation refers only to the vertebra body and abdominal department.

The relation between the vertebral bodies and spinal departments is a permanent one. So, in this process, both departments of lateral parts are independent.

The prospect of further research is to study the influence of various environmental factors on the morpho-functional changes of the sacrum and lumbar spine.

krestec - taz" pri assimetrii sustavnyh shelej krestcovopodvzdoshnogo sustava [The stress-strain state of the kinematic chain "lumbar spine - sacrum - pelvis" with asymmetry of articular cracks of the sacroiliac joint]. Ortopediya, travmatologiya i protezirovanie - Orthopedics, traumatology and prosthetics, 3 (600), 5-14. 
3. Malikov, O. V., Cherkasov, V. H. \& Dzevulska, I. V. (2013). Znachennia anatomichnoho muzeiu dlia vyvchennia anatomi liudyny. Vitchyzniana ta svitova medytsyna: vymohy sohodennia. [The significance of anatomical museum for the study of human anatomy. Domestic and world medicine: the requirements of today]. Dnipropetrovsk - Dnipropetrovsk, 22-24.

4. Cherkasov, V. H., Huminskyi, Yu. Y. \& Kovalchuk, O. I. (2010). Anatomiia: mizhnarodna terminolohiia. [Anatomy: International Terminology]. Vinnytsia: Nova Knyha - Vinnytsya: New Book, 392.

5. Caspar, W., Papavero, L. \& Nabhan, A. (2003). Microsurgical excision of symptomatic sacral perineural cysts: a study of 15 cases. Surg. Neurol., 59, 101-106.

6. Cattaneo, L., Pavesi, G. \& Mancia, D. (2001). Sural nerve abnormalities in sacral perineural (Tarlov) cysts. J. Neurol., 248, 623-624. DOI: 10.1007/s004150170144

7. Demir, M., Mavi, A., Gumusburun, E., Bayram, M., Gロrsoy, S. \& Nishio H. (2007). Anatomical variations with joint space measurements on CT. Kobe J. Med. Sci., 53 (5), 209-217.

8. Dijkstra, P. F. (2007). Basic problems in the visualization of the sacroiliac joint. In A. Vleeming, V. Mooney, R. Stoeckart. (Eds.). Movement, Stability \& Lumbopelvic Pain: Integration of Research and Therapy. Churchill Livingstone, Edinburg, 299-310.

9. Krings, T., Lukas, R. \& Reul, J. (2001). Diagnostic and therapeutic management of spinal arachnoid cysts. Acta Neurochir., 143, 227-235.

10. Kumar, K., Malik, S. \& Schulte, P. A. (2003). Symptomatic spinal arachnoid cysts: report of two cases with review of literature. Spine, 28, 25-29. DOI: 10.1097/ 01.BRS.0000041591.62378.9D.

11. Langdown, A. J., Grundy, J. R. \& Birch, N. C. (2005). The clinical relevance of Tarlov cysts. J. Spin. Disord. Tech., 18, 29-33.

12. Morio, Y., Nanjo, Y. \& Nagashima, H. (2001). Sacral cyst managed with cyst-subarachnoid shunt. Spine, 26, 451 453.

13. Mummaneni, P. V., Pitts, L. H. \& McCormack, B. M. (2000) Microsurgical treatment of symptomatic sacral Tarlov cysts. Neurosurgery, 47, 74-79. doi: 10.3340/jkns.2014.55.2.110.

14. Nadler, S. F., Bartoli, L. M., Stitik, T. P. \& Chen B. (2001). Tarlov cyst as a rare cause of $\mathrm{S} 1$ radiculopathy: a case report. Arch. Phys. Med. Rehabil., 82, 689-690. DOI: 10.1053/ apmr.2001.22353.

15. Ravin, T. (2007). Visualization of pelvic biomechanical dysfunction. Movement, Stability and Lumbopelvic. Churchill Livingstone, Edinburg, 327-339.

16. Radlauer, C (1908). Beitrage zur Anthropologie des Kreuzbeins. Morph. Jahrb., 38.

\section{Список посилань}

1. Головацький, А. С. \& Черкасов, В. Г. (2010). Анатомія лю-

Черкасов В. Г., Маліков О. В.

\section{ФОРМИ КРИЖОВОЇ КІСТКИ ЛЮДИНИ: ЇХ ВИДОЗМІНИ ТА ВЗАЕМОВІДНОШЕННЯ ЧАСТИН}

Анотація. Форма крижової кістки людини і їі зміни повинні розглядатися з точки зору тих впливів - механічних, в першу чергу, які визначають еволюцію функцій хребтового стовбуру людини. Метою дослідження є визначення форми крижової кістки людини та пояснення для її мінливості. Об'єкт дослідження представлений 68 крижовими кістками, отриманими 3 оглядової колекції анатомічних досліджень кафедри анатомії Національного медичного університету ім. Богомольця. Кожна з відомих форм крижової кістки людини являє собою одну зі стадій процесу, суттєвою рисою якогоє "занурення" тіл крижових хребців у загальну масу крижової кістки з одночасною фіксацією зовнішніх країв бокових частин в крижово-клубовому суглобі. В цілому зміна форми крижової кістки є прикладом пристосування до нових механічних умов, а також випадкових зовнішніх впливів. Крижова кістка зазнає постійного впливу численних факторів в кожен момент життя організму, що впливає на основну форму крижової кістки та ї̈ видозміни. На підставі аналізу форми і функцій крижової кістки людини виявляються важливі обставини: по-перше, окремі частини крижової кістки не зберігають постійних взаємовідношень; по-друге, зміна цих взаємовідношень протікає в певній послідовності. Вказана обставина дозволяє розглядати різні форми крижової кістки як дини. Вінниця: Нова Книга, 368.

Напряжённо-деформированное состояние кинематичестаз" при ассиметрии суставных щелей крестцово-подвздошного сустава. Ортопедия, травматология и протезирование, 3 (600), 5-14.

Значення анатомічного музею для вивчення анатоміі дення, Дніпропетровськ, 22-24. Анатомія: міжнародна термінологія. Вінниця: Нова Книга, 392.

excision of symptomatic sacral perineural cysts: a study of 15 248, 623-624. DOI: 10.1007/s004150170144

7. Demir, M., Mavi, A., Gumusburun, E., Bayram, M., G】rsoy, S. \& Nishio H. (2007). Anatomical variations with joint space

8. Dijkstra, P. F. (2007). Basic problems in the visualization of the sacroiliac joint. In A. Vleeming, V. Mooney, R. Stoeckart (E).). Movement, Stability \& Lumbopelvic Pain: : Integration Krings, T., Lukas, R. \& Reul, J. (2001). Diagnostic and therapeutic management of spinal arachnoid cysts. Acta Neurochir., 143, 227-235.

spinal arachnoid cysts: report of two cases with review of 01.BRS.0000041591.62378.9D. 29-33.

12. Morio, Y., Nanjo, Y. \& Nagashima, H. (2001). Sacral cyst managed with cyst-subarachnoid shunt. Spine, 26, 451-

Mummaneni, P. V., Pitts, L. H. \& McCormack, B. M. (2000). Microsurgical treatment of symptomatic sacral Tarlov cysts. Neurosurgery, 47, 74-79. doi: 10.3340/jkns.2014.55.2.110. Tarlov cyst as a rare cause of $\mathrm{S} 1$ radiculopathy: a case report. Arch. Phys. Med. Rehabil., 82, 689-690. DOI: 10.1053/ apmr.2001.22353.

dysfunction. Movement, Stability and Lumbopelvic. Churchill Livingstone, Edinburg, 327-339.

16. Radlauer, C (1908). Beitrage zur Anthropologie des Kreuzbeins. Morph. Jahrb., 38.
11. Langdown, A. J., Grundy, J. R. \& Birch, N. C. (2005). The 
послідовні етапи одного і того ж процесу, що розвивається в даній частині організму людини. Ключові слова: крижова кістка, хребетний стовп, форма, функції.

Черкасов В. Г., Маликов А. В.

ФОРМЫ КРЕСТЦА ЧЕЛОВЕКА: ИХ ВИДОИЗМЕНЕНИЯ И ВЗАИМООТНОШЕНИЕ ЧАСТЕЙ

Аннотация. Форма крестца человека и её изменения должны рассматриваться с точки зрения тех воздействий - механических, в первую очередь, которые определяют эволюцию функций позвоночного ствола человека. Целью исследования является определение формы крестцовой кости человека и объяснение для ее изменчивости. Объект исследования представлен 68 крестцами, полученных из обзорной коллекции анатомических исследований кафедры анатомии Национального медицинского университета им. Богомольца. Каждая из известных форм крестца человека представляет собой одну из стадий процесса, существенной чертой которого является "погружение" тела крестцовых позвонков в общую массу крестца с одновременной фиксацией внешних оконечностей их боковых частей в крестцово-подвздошном суставе. В целом изменение формы крестца представляет пример приспособления к новым механическим условиям, а также случайным внешним воздействиям. Крестец испытывает постоянное воздействие многочисленных факторов в каждый момент жизни организма, что влияет на основную форму крестца и её видоизменения. На основании анализа формы и функций крестца человека обнаруживаются важные обстоятельства: во-первых, отдельные части крестца не сохраняют постоянных взаимоотношений; во-вторых, изменение этих взаимоотношений протекает в определённой последовательности. Указанное обстоятельство позволяет рассматривать различные формы крестца как последовательные этапы одного и того же процесса, развивающегося в данной части человеческого организма.

Ключевые слова: крестец, позвоночный столб, форма, функции. 